\title{
PENGARUH INDEPENDENSI AUDITOR, KUALITAS AUDIT, MANAJEMEN LABA, DAN KOMISARIS INDEPENDEN TERHADAP INTEGRITAS LAPORAN KEUANGAN (Studi Kasus Pada Perusahaan Perbankan Yang Terdaftar di BEI Periode 2014-2017)
}

\author{
Sri Ayem, Dewi Yuliana \\ Prodi Akuntansi Fakultas Ekonomi \\ Universitas Sarjanawiyata Tamansiswa \\ Email: sriayemfeust@gmail.com, d.yuliana23@gmail.com
}

\begin{abstract}
The purpose of this study was to determine the effect of auditor independence, audit quality, earnings management, and independent commissioners on the integrity of financial statements. This research is included in descriptive research. The population in this study are banking companies listed on the Indonesia Stock Exchange (IDX) during 2014-2017. The sample in this study was determined using a purposive sampling method and obtained 25 companies, samples in the 4 years of the annual financial report. The type of data used is secondary data. To find out the influence between independent variables and the dependent variable using the method of multiple regression analysis. The results of this study indicate that auditor independence has no significant effect, audit quality has no significant effect, earnings management has a significant effect, independent commissioners have a significant effect on the integrity of financial statements.
\end{abstract}

Keywords : Auditor Independence, Audit Quality, Profit Management, Independent Commissioner, and Financial Report Integrity

\section{Pendahuluan}

Laporan keuangan adalah hasil dari proses akuntansi yang digunakan untuk berkomunikasi antara data keuangan dengan pihak-pihak yang berkepentingan dengan data perusahaan. Dalam Ikatan Akuntansi Indonesia (2015) menjelaskan bahwa laporan keuangan merupakan struktur yang menyajikan posisi keuangan dalam sebuah perusahaan. Integritas laporan keuangan memberikan informasi yang akurat dan terlepas dari tindakan yang disengaja oleh pihak manajemen untuk memanipulasi laporan keuangan. Integritas laporan keuangan adalah hal yang penting sebab mencerminkan nilai perusahaan. Laporan keuangan yang berintegritas berarti laporan keuangan benar, akurat dan terhindar dari manipulasi data keuangan pada saat proses penyusunannya. Terjadinya skandal-skandal laporan keuangan menyebabkan merosotnya kepercayaan masyarakat khususnya masyarakat keuangan, yang salah satunya ditandai dengan turunnya harga saham secara drastis dari perusahaan yang terkena kasus. Kasus manipulasi laporan keuangan yang dilakukan oleh Bank Bukopin selama 3 tahun terakhir, sehingga Bank Bukopin harus memperbaiki laporan keuangan pada tahun 2015, 2016, dan 2017. Bank Bukopin diduga memanipulasi data kartu kredit selama kurang lebih 5 tahun yang lalu. Jumlah kartu kredit yang dimodifikasi sebanyak 100.000 kartu kredit. Hal ini menyebabkan posisi kredit dan pendapatan berbasis komisi Bukopin bertambah tidak sewajarnya (m.detik.com 2018).

Kasus Bank Bukopin yang memanipulasi data kartu kredit bisa lolos dari layer pengawasan dan audit selama bertahun-tahun, baik dari audit internal Bukopin, maupun dari KAP sebagai auditor independen, BI, dan OJK. Hal ini disebabkan lemahnya kinerja pihakpihak petinggi Bank Bukopin. Laporan keuangan Bank Bukopin ditangani oleh auditor Ernst \& Young (EY) salah satu big four kantor akuntan dan konsultan terbesar di dunia. Hal ini membuat reputasi Kantor Akuntan Publik tersebut menjadi tercoreng (CNBC Indonesia 2018). Kasus manipulasi data keuangan tidak 
hanya dari pihak dalam perusahaan saja yang bertanggung jawab, tetapi pihak luar dari perusahaan juga berpengaruh.

Independensi seorang auditor berarti auditor harus bisa mandiri dan terpisah dari berbagai kegiatan yang diperiksa. Independensi merupakan dasar untuk merumuskan serta menyatakan pendapat atas laporan keuangan yang diperiksa (Santoso 2016). Bagi pemakai laporan keuangan harus memandang Kantor Akuntan Publik (KAP) sebagai pihak yang independen dan kompeten. Hal ini dapat mempengaruhi jasa yang diberikan, maka nilai audit atau kualitas audit juga meningkat, sehingga KAP dituntut untuk bertindak dengan profesionalisme tinggi.

Kualitas audit bisa terwujud apabila memenuhi standar audit yang berlaku umum. Pengguna laporan keuangan menyatakan bahwa kualitas audit terjadi jika auditor dapat memberikan jaminan bahwa tidak ada kesalahan atau kecurangan ( fraud ) dalam menyusun laporan keuangan (Akram et al., 2017). KAP besar mempunyai alasan reputasi dan kekayaan (deep pocket) sehingga memiliki hubungan positif dengan kualitas audit (Hamid $\&$ Solikhah 2017). Penelitian ini membuktikan kesesuaian hipotesis reputasi yang berargumen bahwa KAP besar memiliki insentif untuk mengaudit lebih akurat karena mereka memiliki lebih banyak hubungan spesifik dengan klien yang akan hilang jika mereka memberikan laporan yang tidak akurat.

Manajemen laba adalah sebuah tindakan manajer untuk memaksimumkan atau meminimumkan laba yang dilaporkan dalam penyusunan laporan keuangan dari unit yang menjadi tanggung jawabnya dan tidak memiliki hubungan terhadap perubahan profitabilitas perusahaan dalam jangka panjang. Manajemen laba sebagai upaya manajer perusahaan untuk mempengaruhi informasi laba dalam laporan keuangan (Putra 2012). Informasi yang diberikan manajemen belum dapat dijamin bahwa laporan keuangan yang disajikan sesuai dengan kondisi perusahaan yang sesungguhnya. Salah satu penyebab terjadinya manajemen laba yaitu adanya ketidakseimbangan penguasaan informasi yang dapat memicu timbulnya suatu kondisi yang disebut sebagai asimetri informasi (information asymmetry).
Komisaris independen adalah dewan komisaris yang berasal dari luar emiten atau perusahaan publik dan memenuhi syarat sebagai komisaris independen. Pada sebuah perusahaan terdapat sebuah komisaris independen yang terdiri dari dewan komisaris yang bertugas menilai perusahaan secara keseluruhan. Komisaris independen berguna untuk menyeimbangkan keputusan yang akan diambil oleh kepemilikan saham minoritas. Komisaris independen menjalankan fungsi monitoring agar integritas laporan keuangan yang dihasilkan semakin baik (Widodo 2016).

Terkait dengan fenomena yang terjadi dan banyak topik yang dilakukan oleh beberapa peneliti sebelumnya, penelitian ini mengacu pada penelitian yang dilakukan oleh Abdullah Chello Adriansano dan Nuryantoro (2015) yang berjudul "Pengaruh independensi Auditor dan kualitas audit terhadap integritas laporan keuangan". Perbedaan penelitian terdahulu dengan penelitian ini terletak pada penambahan variabel manajemen laba, komisaris independen, studi kasus, dan tahun penelitian. Tahun penelitian yang sekarang 2014-2017, dan studi kasusnya pada perusahaan perbankan yang terdaftar di BEI. Alasan penambahan variabel manajemen laba karena ingin menegetahui kinerja laporan keuangan khususnya laporan keuangan perbankan apakah ada unsur permainan laba dalam menyusun laporan keuangan yang dilakukan oleh manajer. Serta penambahan variabel komisaris independen untuk mengetahui apakah sudah memenuhi presentase ketentuan untuk posisi komisaris independen yang dibutuhkan. Peneliti memilih perusahaan perbankan sebagai sampel penelitian karena peneliti ingin mengetahui integritas laporan keuangan yang disajikan pada perusahaan perbankan yang terdaftar di Bursa Efek Indonesia sudah sesuai atau masih banyak kecurangan dalam menyusun laporan keuangan. Berdasarkan latar belakang tersebut maka penulis tertarik untuk mengambil judul "PENGARUH INDEPENDENSI AUDITOR, KUALITAS AUDIT, MANAJEMEN LABA, DAN KOMISARIS INDEPENDEN TERHADAP INTEGRITAS LAPORAN KEUANGAN ( Studi Kasus Pada Perusahaan Perbankan Yang Terdaftar di BEI Periode 2014-2017)". 


\section{TINJAUAN PUSTAKA}

\section{Agency Theory}

Teori keagenan atau Agency Theory menjelaskan tentang (kontrak) hubungan antara principal (investor) dan agen (manajer) (Akram et al., 2017). Menurut Jensen dan Meckling (1976) dalam (Santoso 2016) menjelaskan bahwa ada dua bentuk hubungan keagenan, yaitu antara manajer dan pemegang saham (shareholders) serta antara manajer dan pemberi pinjaman (bondholders). Berdasarkan asumsi sifat dasar manusia manajer akan bertindak opportunistic yaitu dimana manajer lebih mengutamakan kepentingan pribadinya daripada kepentingan organisasi. Teori agensi menjelaskan bahwa konfik kepentingan dan asimetri informasi yang muncul dapat dikurangi dengan mekanisme pengawasan yang tepat (Putra 2012).

\section{Teori Stewardship}

Teori Stewardship adalah teori yang menggambarkan dimana situasi manajer tidaklah termotivasi oleh tujuan individu tetapi lebih mengutamakan sasaran dan hasil utama untuk kepentingan organisasi. Teori stewardship didesain untuk menguji situasi para eksekutif dalam perusahaan agar bertindak baik terhadap principalnya, teori ini juga menjelaskan kepentingan bersama dijadikan dasar dari tindakan manajer (Anton 2010). Teori ini menjelaskan filosofi manajemen dan perbedaan budaya organisasi serta kepemimpinan untuk mencapai tujuan bersama tanpa mengorbankan kepentingan individu masing-masing. Hal penting dalam teori stewardship adalah manajer menyelaraskan tujuannya sesuai dengan prinsipal supaya tercipta kerjasama yang baik. Pada teori stewardship manajemen dipercaya untuk bekerja dengan baik untuk kepentingan publik dan shareholder.

\section{Integritas Laporan Keuangan}

Integritas adalah prinsip moral yang tidak memihak, terbuka, jujur, seseorang yang berintegritas tinggi memandang dan mengemukakan fakta apa adanya (Mulyadi 2011:30) dalam (Adriansano \& Nuryantoro 2015). Integritas laporan keuangan menunjukkan sejauhmana laporan keuangan yang disajikan menunjukkan informasi yang sesuai dan jujur. Mengacu pada kasus-kasus perusahaan publik di Indonesia secara intuitif dapat disimpulkan rendahnya integritas laporan keuangan menjadi penyebab perusahaan publik memiliki integritas laporan keuangan yang buruk.

\section{Independensi Auditor}

Independensi merupakan suatu standar auditing yang penting karena opini akuntan independen bertujuan untuk menambah kredebilitas laporan keuangan yang disajikan oleh manajemen. Independensi berarti seorang auditor harus bebas dari pengaruh, tidak mudah dikendalikan oleh pihak lain, dan tidak tergantung pada orang lain (Mulyadi 2011:26) dalam (Adriansano \& Nuryantoro 2015). Sebagaimana dapat dikatakan jika tingkat independensi seorang auditor semakin tinggi maka integritas laporan keuangan dapat dikatakan baik.

\section{Kualitas Audit}

Kualitas audit adalah kapasitas auditor eksternal dalam mendektsi terjadinya kesalahan dan bentuk penyimpangan lainnya dalam (Tussiana \& Lastanti 2016). Kualitas audit adalah proses sistematis untuk mengevaluasi secara objektif bukti yang berkaitan dengan penilaian kegiatan dan peristiwa ekonomi untuk menyampaikan hasilnya kepada pengguna yang berkepentingan. Untuk mengukur kualitas audit dengan mengklasifikasi antara jasa audit dari KAP big four dengan KAP non big four (Widodo 2016). KAP yang besar memiliki reputasi dan pengalaman yang lebih baik daripada KAP yang kecil. Auditor di KAP besar dianggap lebih akurat dibandingkan dengan auditor yang bekerja di KAP yang kecil.

\section{Manajemen Laba}

Manajemen laba terjadi ketika manajer menggunakan kewenangan yang mereka miliki untuk mengubah laporan keuangan, hal ini bertujuan untuk menyesatkan pemangku kepentingan mengenai kondisi ekonomi perusahaan yang sebenarnya. Manajemen laba merupakan tindakan yang dilakukan manajemen untuk mempegaruhi laba yang dilaporkan dalam laporan keuangan (Sari \& 
Rahayu 2014). Manajemen laba diukur dengan menggunakan model Modifikasi Jones. Modifikasi ini dirancang untuk menghilangkan kesalahan manajemen terhadap pendapatan.

\section{Komisaris Independen}

Komisaris independen adalah suatu badan yang dibentuk perusahaan dengan anggotanya yang berisikan dewan komisaris dari luar perusahaan dan memiliki fungsi untuk menilai kinerja manajemen secara keseluruhan, Linata dan Sugiarto (2012:80) dalam (Widodo 2016). Komisaris independen adalah anggota Dewan Komisaris yang berasal dari luar emiten serta telah memenuhi persyaratan sebagai komisaris independen. Pada Peraturan OJK Nomor 33/POJK.04/2014 tentang Direksi dan Dewan Komisaris Emiten atau Perusahaan Publik pada pasal 20 ayat 2 dan 3. Komisaris independen harus mendorong diterapkannya praktik tata kelola perusahaan yang baik. Seorang komisaris independen dapat menyampaikan pendapat yang berbeda dengan dewan komisaris dan harus dimasukan dalam laporan tahunan.

\section{Perumusan Hipotesis}

\section{Pengaruh Independensi Auditor terhadap Integritas Laporan Keuangan}

Independensi adalah standar umum nomor dua yang ditetapkan oleh (Ikatan Akuntansi Indonesia) dalam (Hamid \& Solikhah 2017) yang menyatakan bahwa semua yang berhubungan dengan independensi dan sikap mental harus dipertahankan oleh seorang auditor. Lamanya hubungan antara auditee dengan auditor dapat mengganggu independensi serta keakuratan auditor. Hal ini berarti semakin lamanya hubungan relasi antara KAP-klien dapat mempunyai pengaruh yang merugikan terhadap independensi KAP (Subandono 2015).

Penelitian yang dilakukan oleh Santoso (2016), Subandono (2015) dan Setiawan (2015)menghasilkan temuan bahwa independensi memiliki pengaruh positif terhadap integritas laporan keuangan, sedangkan pada penelitian yang dilakukan oleh Hamid \& Solikhah (2017) menghasilkan temuan bahwa independensi berpengaruh negatif terhadap integritas laporan keuangan.
Penugasan audit yang lama kemungkinan dapat pula meningkatkan independensi karena akuntan publik sudah familiar, sehingga semakin tinggi independensi auditor maka akan semakin baik integritas pelaporan keuangan yang dihasilkan. Berdasarkan uraian tersebut, maka hipotesis alternatif yang dikemukakan adalah sebagai berikut :

\section{H1 : Independensi Auditor berpengaruh positif terhadap integritas laporan keuangan}

\section{Pengaruh Kualitas Audit terhadap Integritas Laporan Keuangan}

Pada penelitian sebelumnya menunjukkan bahwa auditor memiliki berbagai tingkat kualitas audit yang berbeda, hal ini untuk merespon permintaan klien yang berbeda-beda terhadap kualitas audit (Hamid \& Solikhah 2017). Kualitas auditor adalah kemampuan profesional individu auditor dalam melakukan pekerjaannya. KAP yang besar cenderung independen dibandingkan dengan KAP yang kecil. Penelitian yang dilakukan oleh Setiawan (2015) dan Widodo (2016) menghasilkan temuan bahwa kualitas audit berpengaruh positif terhadap integritas laporan keuangan, sedangkan penelitian yang dilakukan oleh Hamid \& Solikhah (2017) dan Tussiana \& Lastanti (2016) menghasilkan temuan bahwa kualitas audit memiliki pengaruh negatif terhadap integritas laporan keuangan.

Dengan demikian semakin tinggi kualitas audit dan semakin besar ukuran KAP maka integritas laporan keuangan yang dihasilkan akan semakin baik. Semakin besar ukuran KAP maka semakin baik integritas laporan keuangan yang dihasilkan. Hal ini dikarenakan KAP besar lebih insentif untuk menghindari hal-hal yang dapat merusak reputasinya. Berdasarkan uraian tersebut, maka hipotesis alternatif yang dikemukakan adalah sebagai berikut:

H2 : Kualitas Audit berpengaruh positif terhadap integritas laporan keuangan

Pengaruh Manajemen Laba terhadap
Integritas Laporan Keuangan 
Dalam laporan keuangan, apabila terjadi kondisi dimana pihak manajemen tidak berhasil mencapai target laba, maka manajemen akan memanfaatkan fleksibilitas yang dimiliki untuk memodifikasi laba yang dilaporkan dalam laporan keuangan (Putra 2012). Adanya asimetri informasi memungkinkan manajemen untuk melakukan manajemen laba. Penelitian yang dilakukan oleh Putra (2012) menghasilkan temuan bahwa manajemen laba berpengaruh positif terhadap integritas laporan keuangan. Sedangkan pada penelitian Sari \& Rahayu (2014) menghasilkan temuan bahwa manajemen laba negatif terhadap integritas laporan keuangan. Dengan demikian jika tingkat manajemen laba yang dilakukan manajemen semakin kecil maka integritas laporan keuangan yang dihasilkan semakin baik. Berdasarkan uraian tersebut, maka hipotesis alternatif yang dikemukakan adalah sebagai berikut:

\section{H3 : Manajemen Laba berpengaruh negatif terhadap integritas laporan keuangan}

\section{Pengaruh Komisaris Independen terhadap Integritas Laporan Keuangan}

Komisaris Independen adalah sebuah badan dalam perusahaan yang beranggotakan dewan komisaris yang independen yang berasal dari luar perusahaan. Komisaris independen berfungsi menilai kinerja perusahaan secara keseluruhan. Komisaris independen menjadi penenggah apabila terjadi perselisihan diantara manajer internal, serta memiliki wewenang memberikan nasehat kepada manajemen (Hamid \& Solikhah 2017). Keberadaan komisaris independen pada perusahaan dapat mempengaruhi integritas laporan keuangan yang dihasilkan. Penelitian yang dilakukan oleh Savero (2017), Setiawan (2015) dan Subandono (2015) menghasilkan temuan bahwa komisaris independen berpengaruh positif terhadap integritas laporan keuangan. Sedangkan penelitian yang dilakukan oleh Hamid \& Solikhah (2017), serta penelitian Santoso (2016) menghasilkan temuan bahwa komisaris independen berpengaruh negatif terhadap integritas laporan keuangan yang dihasilkan.

Keberadaan komisaris independen dapat mempengaruhi integritas laporan keuangan yang disajikan oleh manajemen, karena terdapat badan yang mengawasi dan melindungi hak-hak diluar perusahaan. Jika semakin tinggi presentase komisaris independen dalam perusahaan maka berdampak baik pada integritas laporan keuangan. Berdasarkan uraian tersebut, maka hipotesis alternatif yang dikemukakan adalah sebagai berikut :

H4 : Komisaris independen berpengaruh positif terhadap integritas laporan keuangan

\section{Metode Penelitian}

\section{Populasi, Sampel, dan Teknik Pengambilan Sampel}

Populasi yang digunakan dalam penelitian ini adalah perusahaan perbankan yang tercatat di Bursa Efek Indonesia selama 2014-2017. Sampel penelitian ini menggunakan perusahaan perbankan yang terdaftar di Bursa Efek Indonesia selama 2014-2017. Teknik pengambilan sampel metode purposive sampling dengan kriteria-kriteria yang dipilih sebagai berikut :

1. Perusahaan perbankan terdaftar di BEI selama 2014-2017.

2. Perusahaan menyampaikan laporan keuangan tahunan yang telah diaudit.

3. Perusahaan menyampaikan data secara lengkap selama periode pengamatan berkaitan dengan variabel yang dipakai.

\section{Jenis dan Sumber Data}

Jenis data yang dalam penelitian ini adalah data skunder. Data sekunder merupakan data primer yang telah diolah oleh pihak pengumpul data primer maupun oleh pihak lain (Umar, 2001:69) dalam Subandono (2015). Data penelitian ini meliputi laporan keuangan yang telah dipublikasikasikan selama tahun 2014 sampai dengan 2017.

\section{Metode Pengumpulan Data}

Metode pengumpulan data didalam penelitian ini diperoleh dari laporan tahunan perusahaan perbankan yang terdaftar di Bursa Efek Indonesia selama tahun 2014 - 2017, dan 
dengan mengakses situs laporan keuangan di BEI yaitu www.idx.co.id.

\section{Teknik Analisis Data}

Penelitian ini menggunkan analisis regresi berganda, dengan pengujian statistik deskriptif dan pengujian asumsi klasik. Asumsi klasik yang meliputi uji normalitas, multikolinieritas, autokorelasi, dan heteroskedastisitas. Selanjutnya uji hipotesis dilakukan dengan uji simultan (F), uji hipotesis parsial (uji t), analisis regresi berganda, dan koefisien determinan. Analisis regresi linier berganda yang dinyatakan dalam persamaan:

$$
\mathrm{Y}=\alpha+\beta 1 \mathrm{x} 1+\beta 2 \mathrm{x} 2+\beta 3 \times 3+\beta 4 \mathrm{x} 4+\mathrm{e}
$$

Keterangan:

$\mathrm{Y}$ : Integritas laporan keuangan

X1 : Independensi Auditor

X2 : Kualitas Audit

X3 : Manajemen Laba

X4 : Komisaris Independen

e : Standar Error

$\beta 1-\beta 4$ : Koefisien Regresi

$\alpha$ : Konstanta

\section{Hasil dan Pembahasan}

\section{Hasil Uji t}

\begin{tabular}{lccccc}
\hline & \multicolumn{2}{c}{$\begin{array}{c}\text { Unstandardized } \\
\text { Coefficients }\end{array}$} & $\begin{array}{c}\text { Standardized } \\
\text { Coefficients }\end{array}$ & & \\
\cline { 2 - 4 } \multicolumn{1}{c}{ Model } & $\mathbf{B}$ & $\begin{array}{c}\text { Std. } \\
\text { Error }\end{array}$ & Beta & t & Sig. \\
\hline (Constant) & .171 & .483 & & .354 & .724 \\
INDP AUD & -.077 & .179 & -.043 & -.433 & .666 \\
KUA AUD & .017 & .228 & .008 & .074 & .941 \\
MNJ LB & $2.037 \mathrm{E}-013$ & .000 & .314 & 3.193 & .002 \\
KOMI & 1.750 & .695 & .251 & 2.517 & .014 \\
\hline
\end{tabular}

Sumber: Data diolah SPSS 21 tahun 2018

Berdasarkan tabel tersebut persamaan regresi berganda sebagai berikut : $\mathrm{Y}=0,171-0,077 \mathrm{X} 1+0,017 \mathrm{X} 2+2,037 \mathrm{E} 13 \mathrm{X} 3+1,750 \mathrm{X} 4$

\section{Hasil Uji F}

\begin{tabular}{lccccc}
\hline \multicolumn{1}{c}{ Model } & Sum of Square & Df & $\begin{array}{c}\text { Mean } \\
\text { Square }\end{array}$ & F & Sig. \\
\hline $\begin{array}{l}\text { Regression } \\
\text { Residual }\end{array}$ & 11.521 & 4 & 2.880 & 4.066 & $.004^{\mathrm{b}}$ \\
Total & 67.302 & 95 & .708 & & \\
\hline \multicolumn{4}{c}{ Sumber: Data diolah SPSS 21 tahun 2018 } \\
\hline
\end{tabular}

Berdasarkan tabel tersebut menunjukkan bahwa nilai $\mathrm{F}$ hitung sebesar 4,066 dengan nilai signifikan 0,004 sedangkan nilai $\mathrm{F}$ tabel sebesar 2,31. Hal ini berarti nilai $\mathrm{F}$ hitung lebih besar dari $\mathrm{F}$ tabel, maka model regresi menunjukkan bahwa model regresi dapat digunakan atau dapat dikatakan 
terdapat pengaruh signifikan antara variabel Independensi Auditor, Kualitas Audit, Manajemen Laba, dan Komisaris Independen terhadap variabel Integritas Laporan Keuangan dalam penelitian ini.

\section{Hasil Uji Koefisien Determinan $\left(\mathbf{R}^{2}\right)$}

\begin{tabular}{ccccc}
\hline Model & R & R Square & $\begin{array}{c}\text { Adjusted R } \\
\text { Square }\end{array}$ & $\begin{array}{c}\text { Std. Error of } \\
\text { the Estimate }\end{array}$ \\
\hline 1 & $.382^{\mathrm{a}}$ & .146 & .110 & .84169 \\
\hline
\end{tabular}

Sumber: Data diolah SPSS 21 tahun 2018

Berdasarkan tersebut menunjukkan bahwa nilai $R$ Square sebesar .146 yang berarti 14,6\% integritas laporan keuangan dipengaruhi oleh variabel independensi auditor, kualitas audit, manajemen laba, dan komisaris independen, sedangkan sisanya 85,4\% dipengaruhi oleh variabel lain yang tidak diteliti oleh peneliti.

\section{Pengujian Hipotesis dan Pembahasan}

\section{Pengaruh Independensi Auditor Terhadap Integritas Laporan Keuangan}

Hipotesis pertama yang menyatakan

bahwa independensi auditor berpengaruh positif terhadap integritas laporan keuangan tidak terdukung. Hal tersebut dibuktikan dengan hasil pengujian pada penelitian ini memperoleh nilai signifikan $0,666>0,05$ yang berarti independensi auditor tidak berpengaruh signifikan terhadap integritas laporan keuangan, dengan nilai koefisien independensi auditor sebesar -0,077 dengan menunjukkan hubungan yang negatif. Arah koefisien yang negatif menunjukkan bahwa semakin rendah independensi auditor maka integritas laporan keuangan akan semakin buruk. Hal ini juga didukung oleh uji $\mathrm{t}$ yang menghasilkan nilai $\mathrm{t}$ hitung -0,433 lebih kecil dari t tabel 1,66105. Alasan hipotesis pertama tidak terdukung karena masih banyak perusahaan sektor perbankan yang menggunakan jasa auditor yang sama selama 3 tahun buku berturut-turut.

Temuan penelitian ini mendukung penelitian yang dilakukan oleh Hamid \& Solikhah (2017) yang menunjukkan bahwa independensi tidak berpengaruh signifikan terhadap integritas laporan keuangan, dan memiliki hubungan yang negatif yang berarti semakin rendah independensi auditor maka integritas laporan keuangan semakin buruk. Hasil penelitian ini tidak sesuai dengan penelitian yang dilakukan oleh Santoso (2016), Subandono (2015), dan Setiawan (2015) yang menyatakan bahwa independensi auditor berpengaruh signifikan terhadap integritas laporan keuangan, dan memiliki hubungan yang positif.

\section{Pengaruh Kualitas Audit Terhadap Integritas Laporan Keuangan}

Hipotesis kedua yang menyatakan bahwa kualitas audit berpengaruh positif terhadap integritas laporan keuangan tidak terdukung. Hal tersebut dibuktikan dengan hasil pengujian pada penelitian ini memperoleh nilai signifikan $0,941>0,05$ yang berarti kualitas audit tidak memiliki pengaruh signifikan terhadap integritas laporan keuangan, dengan nilai koefisien sebesar 0,017 menunjukkan hubungan yang positif yang berarti dengan arah koefisien yang positif menunjukkan bahwa semakin tinggi kualitas audit maka integritas laporan keuangan akan semakin baik. Hal ini juga didukung oleh uji $t$ yang menghasilkan nilai $\mathrm{t}$ hitung 0,074 lebih kecil dari t tabel 1,66105. Alasan hipotesis kedua tidak terdukung karena masih ada beberapa perusahaan sektor perbankan yang belum menggunakan KAP big four untuk mengaudit laporan keuangannya.

Perusahaan yang mengaudit laporan keuangan dengan menggunakan KAP big four integritas laporan keuangannya lebih baik daripada yang tidak menggunakan KAP big four. Temuan pada penelitian ini mendukung penelitian yang dilakukan oleh Subandono (2015) yang menunjukkan bahwa kualitas audit tidak berpengaruh signifikan terhadap integritas laporan keuangan, dan memiliki hubungan yang positif antara kualitas audit dengan integritas laporan keuangan hal ini berarti semakin besar kualitas audit dan 
ukuran KAP maka integritas laporan keuangan yang dihasilkan akan semakin baik. Hasil penelitian ini tidak mendukung penelitian yang dilakukan oleh Hamid \& Solikhah (2017), serta penelitian yang dilakukan oleh Tussiana dan Lastanti (2016) yang menyatakan bahwa kualitas audit berpengaruh signifikan terhadap integritas laporan dan menyatakan adanya hubungan negatif antara kualitas audit dengan integritas laporan keuangan yang berarti semakin kecil kualitas audit KAP maka integritas laporan keuangan semakin rendah.

\section{Pengaruh Manajemen Laba Terhadap Integritas Laporan Keuangan}

Hipotesis ketiga yang menyatakan manajemen laba berpengaruh negatif terhadap integritas laporan keuangan tidak terdukung. Hal ini dibuktikan dengan hasil pengujian pada penelitian ini memperoleh nilai koefisien sebesar 2,037E-013 yang menunjukkan hubungan positif yang berarti bahwa semakin besar tingkat manajemen laba maka integritas laporan keuangan akan semakin buruk, dengan nilai signifikan $0,002<0,05$ yang berarti manajemen laba memiliki pengaruh signifikan terhadap integritas laporan keuangan, dengan nilai uji t yang menghasilkan nilai t hitung sebesar 3.193 lebih besar dari t tabel 1,66105 dalam penelitian ini manajemen laba berpengaruh positif terhadap integritas laporan keuangan. Manajemen laba merupakan campur tangan manajemen dalam penyusunan keuangan ekstrnal untuk menguntungkan diri sendiri.

Penelitian ini sesuai dengan teori keagenan asumsi sifat dasar manusia manajer sebagai manusia akan bertindak opportunistic yaitu mengutamakan kepentingan pribadinya. Alasan penelitian ini tidak didukung karena kurangnya mekanisme pengawasan yang tepat di dalam perusahaan, sehingga manajemen memanfaatkan fleksibilitasnya untuk kepentingan pribadi. Hal ini apabila terjadi suatu kondisi dimana pihak manejemen tidak dapat mencapai target laba, maka manajemen akan memanfaatkan fleksibilitas untuk memodifikasi laba yang dilaporkan.

Penelitian ini mendukung penelitian yang dilakukan oleh Putra (2012) yang menyatakan bahwa manajemen laba berpengaruh signifikan terhadap integritas laporan keuangan dan memiliki nilai positif yang berarti semakain besar manajemen laba yang dilakukan maka integritas laporan keuangan akan semakin buruk. Hasil penelitian ini tidak sejalan dengan penelitian yang dilakukan oleh Sari \& Rahayu (2014) yang menyatakan bahwa manajemen laba berpengaruh signifikan dengan integritas laporan keuangan dan memiliki koefisien negatif yang berarti semakin kecil manajemen laba yang dilakukan maka integritas laporan keuangan semakin baik.

\section{Pengaruh Komisaris Independen Terhadap Integritas Laporan Keuangan}

Hipotesis ke empat yang menyatakan komisaris independen berpengaruh positif terhadap integritas laporan keuangan terdukung. Hal tersebut dibuktikan dengan hasil pengujian pada penelitian ini memperoleh nilai signifikan $0,014<0,05$ yang berarti bahwa komisaris independen memiliki pengaruh signifikan terhadap integritas laporan keuangan, dengan nilai koefisien dari komisaris independen pada penelitian ini sebesar 1,750 yang menunjukkan hubungan positif yang berarti dengan koefisien positif menunjukkan bahwa semakin tinggi presentase komisaris independen dalam perusahaan maka integritas laporan keuangan yang dihasilkan semakin baik. Hal ini juga didukung oleh uji t yang menghasilkan nilai $t$ hitung 2,517 lebih besar dari t tabel 1,66105.

Komisaris independen pada suatu perusahaan dapat mempengaruhi integritas laporan keuangan yang dihasilkan oleh manajemen, dengan demikian maka perusahaan yang memiliki komisaris independen yang sesuai maka integritas laporan keuangan yang dihasilkan akan baik. Hasil penelitian ini mendukung penelitian yang dilakukan oleh Savero (2017), Setiawan (2015), dan Subandono (2015) yang menyatakan bahwa komisaris independen berpengaruh signifikan terhadap integritas laporan keuangan dan memiliki hubungan yang positif yang berarti semakin tinggi presentase komisaris independen dalam perusahaan maka integritas laporan keuangan yang dihasilkan semakin baik. Penelitian ini tidak mendukung penelitian yang dilakukan oleh Hamid \& Solikhah (2017) serta penelitian Santoso (2016) yang menunjukkan bahwa komisaris independen tidak berpengaruh 
signifikan terhadap integritas laporan keuangan dan memiliki hubungan negatif yang berarti bahwa semakin rendah presentase komisaris independen dalam perusahaan maka integritas laporan keuangan yang dihasilkan semakin rendah.

\section{Kesimpulan}

Berdasarkan pengujian yang telah dilakukan pada perusahaan perbankan yang terdaftar di Bursa Efek Indonesia tahun 20142017 dapat disimpulkan sebagai berikut :

a. Independensi Auditor tidak berpengaruh signifikan terhadap integritas laporan keuangan pada perusahaan perbankan yang terdaftar di Bursa Efek Indonesia tahun 2014-2017.

b. Kualitas Audit tidak berpengaruh signifikan terhadap integritas laporan keuangan pada perusahaan perbankan yang terdaftar di Bursa Efek Indonesia tahun 2014-2017.

c. Manajemen Laba berpengaruh signifikan terhadap integritas laporan keuangan pada perusahaan perbankan yang terdaftar di Bursa Efek Indonesia tahun 2014-2017.

d. Komisaris Independen berpengaruh signifikan terhadap integritas laporan keuangan pada perusahaan perbankan yang terdaftar di Bursa Efek Indonesia tahun 2014-2017.

\section{Implikasi}

Hasil penelitian ini menunjukkan bahwa variabel independensi auditor dan kualitas audit tidak berpengaruh signifikan terhadap integritas laporan keuangan, sedangkan variabel manajemen laba dan komisaris independen berpengaruh signifikan terhadap integritas laporan keuangan. Penelitian ini memiliki implikasi bagi perusahaan perbankan sebagai bahan evaluasi atas integritas laporan keuangan yang dihasilkan. Untuk meningkatkan independensi auditor maka seorang auditor harus bersikap independen, bebas dari pengaruh dan kompeten. Serta untuk meningkatkan kualitas audit yang baik dapat terwujud dengan memenuhi standar audit yang berlaku umum. Untuk manajer supaya tidak menyalahgunakan informasi yang dimiliki dan harus memiliki mekanisme pengawasan yang tepat supaya dapat menyelaraskan kepentingan berbagai pihak.

\section{Keterbatasan}

Berdasarkan data yang dikumpulkan dan pengujian yang dilakukan pada perusahaan perbankan yang terdaftar di Bursa Efek Indonesia tahun 2014-2017, penelitian ini memiliki beberapa keterbatasan yang memerlukan penyempurnaan di penelitian selanjutnya antara lain sebagai berikut :

a. Data terjadi autokorelasi negatif.

b. Populasi dan sampel yang digunakan dalam penelitian hanya 25 perusahaan perbankan yang terdaftar di Bursa Efek Indonesia

c. Periode penelitian hanya 4 tahun yaitu dari tahun 2014-2017.

d. Variabel yang diuji hanya 4 variabel yaitu independensi auditor, kualitas audit, manajemen laba, dan komisaris independen terhadap integritas laporan keuangan.

\section{Saran}

Berdasarkan keterbatasan yang telah disampaikan maka peneliti memberikan beberapa saran untuk penelitian selanjutnya sebagai berikut :

a. Perusahaan perbankan diharapkan tidak menggunakan jasa auditor yang sama selama 3 tahun buku berturut-turut. Hal ini mengacu pada Peraturan Menteri Keuangan No. 17/PMK.01/2008 tentang pemberian jasa audit umum atas laporan keuangan dari suatu entitas.

b. Perusahaan perbankan sebaiknya lebih meningkatkan pengawasan di dalam perusahaan supaya dapat menyelaraskan kepentingan berbagai pihak.

c. Peneliti selanjutnya sebaiknya menambah populasi, sampel, periode penelitian yang lebih banyak atau menggunakan sampel dan populasi perusahaan selain perbankan yang terdaftar di Bursa Efek Indonesia.

d. Menambah variabel independen lain seperti reputasi auditor, audit tenure, financial distress dan variabel lainnya. 


\section{DAFTAR PUSTAKA}

Adriansano, Abdullah Chello, \& Nuryantoro. 2015. "Pengaruh Independensi Auditor Dan Kualitas Audit Terhadap Integritas Laporan Keuangan ( Studi Pada Perusahaan Sektor Properti Dan Real Estate Yang Terdaftar Di BEI Periode 2009-2013 )." Akuntansi Fakultas Ekonomi dan Bisnis Universitas Telkom, Bandung 2(1): 1-8.

Akram, Prayitno Basuki, \& Budiarto. 2017. "Pengaruh Mekanisme Corporate Governance, Kualitas Audit, Ukuran Perusahaan Dan Leverage Terhadap Integritas Laporan Keuangan.” 2(1): 126.

Anton, FX. 2010. "Menuju Teori Stewardship Manajemen." Majalah Ilmiah Informatika 1: 1-20.

CNBC Indonesia. 2018. 27 April 2018. https://www.cnbcindonesia.com/market/ 20180427165905-17-12847/bukopinrevisi-laporan-keuangan-begini responsernst-young (diakses 15 Oktober 2018).

Hamid, Muda Setia, \& Nur Solikhah. 2017. "Pengaruh Independensi, Mekanisme Corporate Governance, Dan Kualitas Audit Terhadap Integritas Laporan Keuangan (Studi Empiris Perusahaan Manufaktur Yang Terdaftar Di Bursa Efek Indone." Jurnal Akuntansi 5(2): 112.

Ikatan Akuntansi Indonesia. 2015. Standar Akuntansi Indonesia. Jakarta: Ikatan Akuntansi Indonesia.

m.detik.com. 2018. "Bank Bukopin Permak Laporan Keuangan, Ini Kata BI Dan OJK." $27 \quad$ April 2018. https://m.detik.com/finance/moneter/d3994551/bank-bukopin-permak-laporankeuangan-ini-kata-bi-dan-ojk (diakses 7 Oktober 2018).

Mulyadi. 2011. Auditing. ed. Salemba Empat. Jakarta: Salemba Empat.

Putra, Daniel Salfauz Tawakal. 2012. "Pengaruh Independensi, Mekanisme Corporate Governance, Kualitas Audit, Dan Manajemen Laba Terhadap Integritas Laporan Keuangan." Seminar Nasional Ekonomi dan Bisnis: 1-63.

Santoso, Didik Adityo Budi. 2016. "Pengaruh Independensi, Corporate Governance
Dan Kualitas Audit Terhadap Integritas Laporan Keuangan (Studi Pada Perusahaan Property Dan Real Estate Yang Terdaftar Di BEI Tahun 20122014)." : 1-51.

Peraturan OJK Nomor 33/POJK.04/2014 tentang Direksi dan Dewan Komisaris Emiten atau Perusahaan Publik

PSAK No. 1 Tahun 2015 Tentang Penyajian Laporan Keuangan

sahamok.com (diakses 02 Oktober 2018)

Sari, Ratna Mirda, \& Sri Rahayu. 2014. "Analisis Pengaruh Independensi Auditor, Mekanisme Corporate Governance, Kualitas Audit, Dan Manajemen Laba Terhadap Integritas Laporan Keuangan." Seminar Nasional Ekonomi dan Bisnis: 1-7.

Savero, Daniel Oscar. 2017. "Pengaruh Komisaris Independen, Komite Audit, Kepemilikan Institusional, Dan Kepemilikan Manajerial Terhadap Integritas Laporan Keuangan." JOM Fekon 4(1): 1-15.

Setiawan, Budi. 2015. "Pengaruh Independensi, Kualitas Audit Dan Mekanisme Corporate Governance Terhadap Integritas Laporan Keuangan Perusahaan Manufaktur Di Bursa Efek Indonesia Tahun 2008-2012." JOM Fekon 2(2): 1-15.

Subandono, Sigid. 2015. "Pengaruh Independensi, Mekanisme Good Corporate Governance Dan Kualitas Audit Terhadap Integritas Laporan Keuangan." Journal Of Accounting: 123.

Tussiana, Ayu Anisa, \& Sri Hexana Lastanti. 2016. "Pengaruh Independensi, Kualitas Audit, Spesialisasi Industri Auditor Dan Corporate Governance Terhadap Integritas Laporan Keuangan." Media Riset Akuntansi, Auditing \& Informasi 16(1): 1-10.

Widodo, Bayu. 2016. "Pengaruh Independensi, Kepemilikan Institusional, Kepemilikan Manajerial, Komisaris Independen, Ukuran Perusahaan, Dan Kualitas Audit Terhadap Integritas Laporan Keuangan ( Studi Empiris Pada 
Perusahaan Manufaktur Yang Terdaftar

Di Bursa Efek I." Ekonomi Akuntansi: 1-

18.

www.idx.co.id (diakses 04 Oktober 2018) 